\title{
四 \\ Is Reform in Accounting Education Needed in China and Russia: A Literature Review
}

\author{
Theodore T. Y. Chen ${ }^{1}$
}

\begin{abstract}
The purpose of this study is to examine, through literature review, whether China and Russia are in need of accounting education reforms when they are not English-speaking, do not have developed accounting systems as major English-speaking countries do, have a different political orientation from the selected English-speaking countries and are at a transition stage from a state-planned economy to a market-driven economy.

The paper is based entirely on literature review of global forces at play on accounting education reform, accounting education change in selected English-speaking countries and developments in accounting education in Russia and China.

The review indicates that the two countries have a desperate need for accounting education change and that gradual changes are taking place in both countries, although China is at a more advanced stage of development because of its international trade. There are signs of both countries leaning towards the direction of the Accounting Education Change Commission's (AECC) initiatives. China is focusing more on breadth of education than specialization and Russia is at a preliminary stage having to enhance its financial reporting system.

The available literature on accounting education in Russia and China is limited, particularly in Russia as the Soviet's old system did not offer accounting degrees. However, this does not present a problem in identifying an accounting education trend in these two countries from the available literature as explained in the final section of this paper "Limitations of This Study and Future Research".

With major English-speaking and non English-speaking countries leaning towards AECC in their accounting education reforms regardless of the political orientation of the country, one may conclude that AECC is the direction that developing countries having the same need for change should consider. The comparison made in this paper provides insights into an area that received little or no attention in the past.
\end{abstract}

JEL Classification: A23, I21, M40.

Keywords: Accounting Education, Literature review, Reform, China, Russia.

\footnotetext{
${ }^{1}$ Hong Kong Shue Yan University, tedchen@hksyu.edu
} 


\section{Introduction}

The purpose of this paper is to determine from literature review pertaining to the need and implementation of accounting education change in the two countries, whether the two selected countries are experiencing the same need for accounting education change as in the United States and if so, whether any changes were implemented or are leaning towards implementation. If commonalities exist among these countries in terms of the need and implementation direction, then a specific direction can be identified for developing countries to follow in their development of a sound university accounting programme, both in terms of its curriculum and pedagogy, regardless of their political orientations.

For ease of comparison, the discussion for the two countries will be organized under five headings, namely: (a) Background, (b) Need for Accounting Education Reform, (c) Observations and Thoughts from Academics, (d) Implementation of Changes, if any, and (e) Discussion. Further review of literature leads to the following section, pointing out that accounting education change is not confined to any single country.

\section{Global forces for change in accounting education}

Numerous authors have discussed global forces exerting pressure on accounting education change, including (Albrecht \& Sack, 2001; Mohamed \& Lashine 2003; Nelson, 1995). However, none were as comprehensive and thorough on the topic as Karreman, Ahern, Kuijl and Marrian (2007). Karreman et al (2007), through the combined efforts of a group of authors from the United States, the United Kingdom and the Netherlands, conducted a review of global developments of accounting education over the last decade, involving respondents from 32 professional bodies in 25 countries. The report identified the following global forces:

Unrelenting competitive pressure

Impact of information and technologies

Globalization of business

Focus on fair value accounting

Demand for new knowledge and skills

Demand for improvements in corporate governance and ethics.

\section{Global assumptions underlying the need for change}

The Karreman report postulated a set of assumptions that underlie the development and improvement of accounting education globally. These assumptions concluded that the modern professional accountant needs both broad knowledge and specialized skills and that the future accountant needs training in ethics and objectivity. The assumptions supported the United States Accounting Education Change Commission (AECC) initiatives (Williams, 1993). Furthermore, of the 14 institutes (12 from English-speaking countries) that reported development or change did so in seven areas, including case study at final level of assessment, integrative assignments and assessment, soft skills in examinations and ethics. These changes are also covered, to a large extent, in the AECC initiatives. 
The aforementioned indicates that there are external forces at play that necessitate the need for change in accounting education and that changes taking place thus far are primarily in English-speaking countries and localities, using the US AECC initiatives as a framework in developing the generic competencies required by the accounting profession. Later on, further evidence is provided from literature review on this matter, using the two non-English speaking countries.

\section{Situations in Selected English-speaking Countries}

The United States was the first country that identified the need for accounting education reform as accounting practitioners felt that curriculum and pedagogical considerations placed heavy emphasis on the technical aspects of accounting at the expense of a general, broad-based education. Accounting graduates lacked the critical thinking, problem-solving, communication and many other generic skills deemed essential for entry-level accountants. The Accounting Education Change Commission (AECC) was formed in 1989 with a mandate of resolving this problem. The aforementioned situation was mentioned by numerous authors (Langenderfer,1987; Nelson,1995; Subotnik, 1987; Zeff ,1989) in the United States from the eighties to the nineties. Even after the implementation of the 150-semester hour requirement of the American Institute of Certifies Public Accountants (AICPA) in 2000, the problem of practitioners' complaint was universities' accounting curricula drilled students in rote technical memorization at the expense of the broader business, communication and analytical skills they needed in a real world, continued (Myers, 2005).

Notably, much of the accounting education literature in the new millennium comes in the form of repeating the spirit of AECC requirements. For example, Albrecht and Sack (2000, 2001) reported on the severity of the problems facing accounting education as a result of changes in business from globalization, technology and investor power in the capital markets. Williams (2000) and French and Coppage (2000) all described the challenges facing accounting education and the profession, most of which were curriculum-related and teaching approach-related and were covered in the AECC initiatives. Burnett (2003) identified four top-rated professional skills essential for accounting graduates, being analytical / critical thinking, written communication, oral communication and decision-making. Again, these were suggested by AECC.

Many English-speaking countries are followers of AECC initiatives. A large number of authors in the United Kingdom (UK), Australia and New Zealand cited the use of AECC initiatives and referred to a long list of related articles written by accounting academics in the United States, particularly the Albrecht and Sack $(2000,2001)$ publications on the perilous future of the accounting profession. For situations in the UK, these authors include Byrne and Flood (2003 , 2005), Dewing and Russell (1998), Gray and Collison (2002), Hill and Milner (2005), Lyall (1985). For situations in Australia and New Zealand, the authors include Cable et al (2007), Carr and Mathews (2004), Henderson (2001), Mathews (1990), Mathews (1994, 2001 a,b), Subramaniam (2003), Tippett (1992), and Wolnizer (2004). The need for accounting education reform was not confined to English-speaking countries. 


\section{Situations in Non English-speaking Countries}

Russia and China have been selected for this category of countries as both have large economies, both have been through the transition stage of having to convert from a state-planned economy accounting system to a market-based accounting system, although China is in a much more advanced stage of accounting education development with signs of the AECC impact.

\section{$\underline{\text { Russia }}$}

Practically, very little academic literature is available on Russian accounting education as the Soviet's old system did not offer accounting degrees, but rather students took one or two accounting courses in the economics programme under the planned-economy regime (McGee, 2003). The only available studies in the new millennium were from the works of Preobragenshkaya and McGee, in the form of conference presentations and working paper series.

\section{Background}

The accounting certification system in Russia and some of the former Soviet states is viewed as corrupt (Preobragenskaya \& McGee, 2004). There was lack of confidence in Russian financial statements as one could purchase an accounting certificate in Russia while the private sector was attempting to provide a solution to this lack of credibility by international certification (Preobragenskaya \& McGee, 2004). On the other hand, few Russian accountants possessed internationally recognized certification with certified statements next to meaningless unless certified by one of the big four auditing firms. The Russian government refused to recognize or grant reciprocity to internationally recognized accounting bodies, although Armenia adopted the ACCA model and granted reciprocity for those passing the English ACCA exams. The US CPA was perceived by the market to be the highest quality although the government did not recognize it. The hurdle was that these exams were only in English and were written in the US. Russian students did not meet the 150-hour requirement either (Preobragenskaya \& McGee, 2004).

Russia adopted the International Financial Reporting Standards (IFRS) in 2004, a year ahead of the European Union. However, very few Russian accountants were familiar with IFRS (McGee, 2005; Preobragenskaya \& McGee, 2004). There was no incentive to learn IFRS as the big four auditing firms served most of the market.

Some of the former Soviet's states like Armenia retained the Russian system of accounting after the Soviet Union breakup and were still highly centralized. There were no balance sheets or income statements, and ratios need not be computed, although they had journal entries and a statement that resembled a funds statement (McGee, 2003). On the other hand, Romania went for the French accounting system and Hungary went for the German system (Preobragenskaya \& McGee, 2002). In comparison, Russia's accounting profession is now further up the learning curve than accounting professions in Armenia and Bosnia as some Russian professors are already familiar with IFRS.

\section{Need for Accounting Education Change}

As previously mentioned, the Soviet's old system did not offer accounting degrees. McGee (2003) reported that in response to the change to market-based economy, they had to either model the accounting programme on the US system of taking ten accounting courses plus 
business courses or follow the IFRS. The latter was adopted, using the ACCA syllabus with no multiple choice questions in the exams (in contrast with the US CPA exams).

Practitioners now must be educated under the new system with some professors teaching IFRS while others still teaching the old system. By 2002, 26.6\% of Russian universities taught accounting (Preobragenskaya \& McGee, 2003).

Although IFRS was incorporated into the accounting curriculum, it was difficult to find good learning materials with lack of professors teaching it. Training was carried out by the big four auditing firms. At the same time, students and practitioners used to work with documents and therefore, accruals were difficult to understand. Journals were practitioner-oriented rather than scholarly and lectures were too theoretical and not practical as professors did not have practical experience (McGee \& Prebragenskaya, 2005).

\section{Observations and Thoughts from Academics}

Preobragenskaya and McGee (2003) found that Russian students had very few elective options while US students had a large selection. The majority of students went for a five-year specialist programme while it would take four years to get a bachelor's degree and six years to get a master's degree in Russia. The five-year programme would be similar to the AICPA requirement since 2000. In addition, the authors noted that at St. Petersburg State Polytechnic University, of the hours devoted to the top ten subjects for accounting majors, the top five were in: (a) foreign languages, (b) information science, (c) physical training, (d) mathematics and (e) theory of economics, in that order (Preobragenskaya \& McGee, 2003). This would be observing the AECC spirit with general, conceptual and information technology courses being focused.

McGee (2005) on the other hand studied the situation with Ukrainian universities and found that accounting students there spent longer time studying both accounting and other subjects than in the US. The US students were at the bottom of the scale on math and science while Ukrainian students were the reverse. Hence, Ukrainian universities could demand more, but the quality of their textbooks was not as good, with less examples and many universities did not have any auditing courses. There was also a higher percentage of high school graduates entering universities in the U.S.

Implementation of Changes, If Any

Although there are no implementations of significant changes, the following developments are worth noting:

In 2001, the United States Agency for International Development (USAID) gave regionally recognized an accounting certification in the Russian language similar to ACCA and US CPA exams (McGee \& Preobragenskaya, 2005).

USAID offered Armenia the accounting reform programme, making it possible for them to obtain a marketable credential in more than 100 countries. This helped the adoption of IFRS and International Standards of Auditing (ISA) (McGee, 2003).

At the Odessa State Economic University, the first year was devoted to all general subjects, using a combination of lectures, seminars and cases (McGee \& Preobragenskaya, 2005). This in the author's mind, is following the spirit of AECC initiatives. 
In the USAID accounting reform project, Gray and Needles (1999) translated for financial accounting and Horgren et al (2000) translated for management accounting (Preobragenskaya \& McGee, 2002).

These developments are slow in their evolutionary process. Nevertheless, they represent steps in the right direction.

\section{Discussion}

The need for change is different in Russia from the English-speaking countries as the country needs to change to a new system under the market economy. However, with the exceptions of Odessa State University and St. Petersburg State University where there were signs of the AECC spirit (McGee \& Preobragenskaya, 2003, 2005), Russia is still in the stage of catching up with the rest of the world in developing a sound accounting system.

\section{$\underline{\text { China }}$}

Background

Chau and Chan (2001) indicated that China's accounting reform was the result of economic reforms. The increase in Chinese shares recently on the Hong Kong stock market provided China with a significant source of financing for economic development. Under a centrally planned economy, the major objective of accounting was directed towards accountability and stewardship. Since 1979 China adopted an open door policy, a shift from the closed-door policy, which was in place for decades (Chau \& Chan, 2001 citing Tang, 1996). Accounting reforms in China went through three phases: (a) accounting for foreign-invested enterprises, (b) accounting for share enterprises, and (c) accounting standards.

Lin's (1998) study concluded that the gap between Chinese public accounting and the practices in the rest of the world had been narrowed down remarkably, benefiting both Chinese and western business communities. Training, however, was based on old accounting systems while CPA exams in China incorporated internationally accepted accounting and auditing practices.

\section{Need for Accounting Education Change}

More recently, Yapa and Zhen (2007) found that accounting profession in China has so far failed to take appropriate measures to align the professional accounting development with that of parallel professions as found in western countries. This was due to the lack of co-ordination among accounting educational institutions and the China Institute of Certified Public Accountants (CICPA) purposely exerting control over the supply of accountants by limiting the membership only to those who complete its own exams.

Tang (2000) also identified a bumpy road leading to internationalization of accounting development in China as a result of the difficulty in accounting standard-setting, use of financial information different from other countries, emphasizing reliability of accounting information rather than relevance, lack of independent status of CPA firms and the CICPA, neglect of professional ethics, etc. Chen, Jubb and Tran (1997) also discussed the problems of unifying accounting practices in the PRC and harmonizing them with international practices. Unlike 
accounting evolution in Australia, the UK and the US, the accounting reform in the PRC appeared to be a revolution.

\section{Observations and Thoughts from Academics}

China is working towards the spirit of the AECC initiatives, although not proactively. Chan and Rotenberg (1999) noted the doubling of accounting education in China since the 1980s. However, accounting education tended to stress the recording and reporting aspects of the accounting process and not the more important theoretical and logical analyses of accounting issues such as forecasting, planning, analysis and control as well as the lack of qualified teachers to teach the appropriate courses. Responding to these concerns, the State Education Commission selected two key departments of accounting, one at Xiamen University and the other at the Shanghai University of Finance and Economics (SUFE), to gain expertise for developing doctoral, master's and bachelor's programmes up to international standards, to search for solutions to theoretical as well as practical problems emerging in economic reforms, accepting and directing foreign visiting scholars and undertaking high-level research projects and to join various international academic exchanges.

From the students' angle, Xiao and Dyson (1999) found that students' perception of good accounting teaching are being knowledgeable, the adoption of effective teaching approaches, being responsible and conscientious, making teaching interesting, an ability to encourage and facilitate independent thinking, etc. Similar to AECC initiatives, increased attention was paid to learning and interpersonal skills, writing and oral communication, conference presentations, foreign languages, information technology and similar matters.

From the employers' point of view, Xiao and Dyson (1999) found that prospective employers placed more emphasis on overall ability rather than just technical competence. Unfortunately, the traditional teacher-centred approach was still being used while the innovative strategies were seldom adopted.

\section{Implementation of Changes, If Any}

Looking at the education side, it is encouraging that higher education in general in China has been moving from specialization to breadth with the gradual phasing out of specialized universities (Mohrman, 2003). However, this effort has not entirely impacted on accounting education. More recently, Lin, Xiong and Liu (2005) using the US accounting education reform as background and AECC initiatives as a base, found that accounting educators, students and practitioners in China were all dissatisfied with the present delivery of the needed knowledge and skills and that accounting education reform in China is not only necessary, but imperative.

\section{Discussion}

Unlike the English-speaking countries, it does not appear that China is making any substantial effort towards conforming with the AECC spirit (Lin, et al., 2005) although there are some indications for education in general (Xiao and Dyson 1999) towards that direction. The country is more preoccupied with aligning professional accounting development with that of parallel professions as found in western countries (Yapa \& Zhen, 2007), than dealing with curriculum and pedagogical issues to nurture students' generic skills. 


\section{Concluding Remarks}

English-speaking countries in general are experiencing the same external forces at play as the U.S. and have headed towards accounting education reforms along the lines of AECC initiatives. Hence, reformers of accounting education in developing countries should consider the adoption of AECC initiatives as a basis for curriculum development and pedagogical considerations if their needs for change are similar to those experienced by the English-speaking countries. This consideration for adoption is independent of the political orientation of the country as one can see that the two countries with one still having a communist background, have signs of change in accounting education towards the direction of the AECC spirit, although China is in a more advanced stage of development as a result of its extent of international trade. Hence, China focuses on breadth rather than specialization, While Russia still has considerable work to do in enhancing its financial reporting. This change towards the AECC direction would be particularly useful if and when communist countries move from a state-planned economy accounting system to a market-driven economy accounting system.

In the new millennium, the Pathways Commission (PC) on Accounting Higher Education (2012) made seven recommendations in its final report of which only recommendations 3 and 4 relate to curriculum and pedagogy. This would be the eventual model that accounting higher education globally should consider. However, developing countries and communist countries are not at that stage yet. Their priority should be implementing teaching and curriculum innovations as a start before integrating accounting research, education and practice, exploring alternative pathways to terminal degrees and attracting high-potential, diverse entrants into the profession. Furthermore, as PC is new even to the US, there is no evidence that other Englishspeaking countries are coming up with similar initiatives. Let us give it another ten years and repeat this study to find out whether Pathways Commission is relevant.

\section{Limitations of This Study and Future Research}

Unlike the selected English-speaking countries, accounting education literature pertaining to the two countries is limited, particularly with respect to Russia. However, the available literature provides some background information on accounting education in these countries and the overall direction in which accounting education is heading. Hence, readers of this article can come to the same conclusion as described in the Concluding Remarks section.

As more international trade takes place in Russia, there will be more demands from accounting practitioners in that country on the skill sets of accounting graduates to meet their needs. The accounting bodies representing the practitioners will in turn exert pressure on accounting academics to change their curriculum and pedagogical considerations. As changes take place in the academic institutions, Russian accounting academics will be in a position to survey these changes at selected universities and whether Russian accounting practitioners are satisfied with their accounting graduates. The ensuing research publications can be used by other researchers to duplicate this study with updated information. This future research will confirm whether Russia is truly heading towards the AECC direction. In the case of China, Lin et al (2005) have already used the US accounting education reform as background and AECC initiatives as a base, in finding that accounting educators, students and practitioners were all 
dissatisfied with the present delivery of the needed knowledge and skills. Similar future research can also be conducted to confirm the direction of the change in China, albeit a slow one.

\section{References}

Albrecht, W. S., and Sack, R. J. (2000) Accounting Education: Charting the Course through a Perilous Future. Accounting Education Series, Vol. 16, American Accounting Association: Sarasota, U.S.A.

Albrecht, W. S., and Sack, R. J. (2001). The Perilous Future of Accounting Education. The CPA Journal, 71(3), pp.17-23.

Burnett, S. (2003).The Future of Accounting Education: A Regional Perspective. Journal of Education for Business, 78(3), pp.129-134. http://dx.doi.org/10.1080/08832320309599709

Byrne, M., and Flood, B. (2003). Defining the Present and Shaping the Future: The Changing Nature of Accounting Education in Ireland. Journal of Accounting Education, 21(3), 197213. http://dx.doi.org/10.1016/S0748-5751(03)00025-3

Byrne, M., and Flood, B. (2005). A Study of Accounting Students' Motives, Expectations and Preparedness For Higher Education. Journal of Further and Higher Education, 29(2), pp.111-124. http://dx.doi.org/10.1080/03098770500103176

Cable, D., Dale, M., and Day, R. (2007). Accounting Education: The Gap between Academic Study and Professional Practice, Proceedings of the Second Innovation in Accounting and Corporate Governance Education Conference, pp.1-6.

Carr, S., and Mathews, M. R. (2004). Accounting Curriculum Change and Iterative Programme Development: A Case Study. Accounting Education, 13(Supplement 1), pp.91-116. http://dx.doi.org/10.1080/0963928042000310814

Chan, M. W. L., and Rotenberg, W. (1999). Accounting, Accounting Education, and Economic Reform in the People's Republic of China. International Studies of Management and Organization, 29 (3), pp.37-53.

Chau, G., and Chan, T. (2001). Challenges Faced by Accountancy Education during and beyond the Years of Transition - Some Hong Kong Evidence. Journal of Accounting Education, 1 19(3), pp.145-162. http://dx.doi.org/10.1016/S0748-5751(01)00016-1

Chen, Y., Jubb, P., and Tran, A. (1997). Problems of Accounting Reform in the People's Republic of China. The International Journal of Accounting, 32(2), pp.139-153. http://dx.doi.org/10.1016/S0020-7063(97)90022-4

Dewing, I. P., and Russell, P. O. (1998). Accounting Education and Research: Zeff's Warnings Reconsidered. British Accounting Review, 30(3), pp.291-312.

http://dx.doi.org/10.1006/bare.1998.0072 
French, G. R., and Coppage, R. E. (2000). Educational Issues Challenging the Future of the Accounting Profession. Ohio CPA Journal, 59(3), pp.69-73.

Gray, R., and Collison, D. (2002).Can't See The Wood For The Trees, Can't See The Trees For The Numbers? Accounting Education, Sustainability and the Public Interest. Critical Perspectives on Accounting, 13(5), pp.797-836.

http://dx.doi.org/10.1006/cpac.2002.0554

Gray, S. J., and Needles, B. E. (1999). Financial Accounting: A Global Approach. Houghton Mifflin College Division.

Henderson, S. (2001). The Education of Accountants - A Comment. Accounting Forum, 25 (4), pp.398-401. http://dx.doi.org/10.1111/1467-6303.00074

Horgren. C. T, Bhimani, A., Datar. S. M, and Foster. G. (2002). Management and Cost Accounting. 2nd ed. Rotolito Lombardia: Prentice Hail.

Hill, W. Y., and Milner, M. M. (2005). Transferable Skills in Accounting Education: Examining the Undergraduate Honours Degree Programmes in Scotland, A Best Research Report. Available at SSRN 1013526. http://dx.doi.org/10.2139/ssrn.1013526

Karreman, G. H., Ahern Jr. J. T., Kuijl, J. G. and Marrian, I. F. Y. (2007). GAE 2007 Trends in Global Accounting Education, In Royal Nivra, Amsterdam, pp.1-136..

Langenderfer, H. Q. (1987). Accounting Education's History - A 100-year Search for Identity. Journal of Accountancy, 163(5), pp.302-331.

Lin, Z. J. (1998). Internationalization of Public Accounting: Chinese Experience. Managerial Auditing Journal, 13(2), pp.84-94. http://dx.doi.org/10.1108/02686909810202773

Lin, Z. J., Xiong, X., and Liu, M. (2005). Knowledge Base and Skill Development in Accounting Education: Evidence from China. Journal of Accounting Education, 23(3), pp.149-169. http://dx.doi.org/10.1016/j.jaccedu.2005.06.003

Lyall, D. (1985).Content Levels in Undergraduate Accounting Courses - Views from Industry and The Profession. British Accounting Review,17(1), pp.40-48.

Mathews, M. R. (1994).An Examination of the Work of the Accounting Education Change Commission 1989-1992. Accounting Education, 3(3), pp.193-204. http://dx.doi.org/10.1080/09639289400000019

Mathews, M. R. (2001). The Way Forward for Accounting Education? A Comment on Albrecht and Sack 'A Perilous Future. Accounting Education, 10(1), pp.117-122.

http://dx.doi.org/10.1080/09639280110050277 
Mathews, M. R. (2001).Whither (Or Wither) Accounting Education in the New Millennium, Accounting Forum, 25(4), pp.380-394. http://dx.doi.org/10.1111/1467-6303.00072

Mathews, R. L. (1990). Accounting in Higher Education: Report of the Review of the Accounting Discipline in Higher Education. Department of Employment, Education and Training, Vol. 1. Canberra: Australian Government Publishing Service.

McGee, R.W. (2003). Reforming Accounting Education in a Transition Economy: A Case Study of Armenia. Paper presented at the meeting of the Twelfth Annual World Business Congress of The International Management Development Association (IMDA), Vancouver, Canada. http://dx.doi.org/10.2139/ssrn.408980

McGee, R.W. (2005).A Comparative Study of Accounting Education in Ukraine and the USA. Andreas School of Business Working Papers Series, Barry University, USA. http://dx.doi.org/10.2139/ssrn.813325

McGee, R.W., and Preobragenskaya, G. G. (2005). Accounting Reform in Transition Economies: A Case Study of Ukraine. Paper presented at the meeting of the Fifth Annual International Business Research Conference, Jacksonville, Florida.

http://dx.doi.org/10.2139/ssrn.686430

Mohamed, E. K. A., and Lashine, S. H. (2003). Accounting Knowledge and Skills and the Challenges of a Global Business Environment. Managerial Finance, 29(7), pp.3-13. http://dx.doi.org/10.1108/03074350310768319

Mohrman, K. (2003).Higher Education Reform in Mainland Chinese Universities: An American's Perspectiv. Hong Kong America Center ,Chinese University of Hong Kong.

Myers, R. (2005). Accounting Education Changes Course. Journal of Accountancy, 200(4), pp.108-110.

Nelson, I. T. (1995).What's New about Accounting Education Change? An Historical Perspective on the Change Movement. Accounting Horizons, 9(4), pp.62-76.

Pathways Commission on Accounting Higher Education Final Report (2012), American Accounting Association

http://www.iasplus.com/en/othernews/research-and-education/pathways-commission-onaccounting-higher-education-releases-final-report

Preobragenskaya, G. G., and McGee, R. W. (2002). Reforming the Accounting Curriculum in Russia: Some Guidelines Based on the Armenian and Bosnian Experiences. Andreas School of Business Working Papers Series, Barry University, USA.

Preobragenskaya, G. G., and McGee, R. W. (2003). Accounting Education in a Transition Economy: A Case Study of Russian Universities. Paper presented at the meeting of the 
Academy of International Business - Southeast, Annual Conference, Clearwater, Florida, U.S.A.

Preobragenskaya, G. G., and McGee, R. W. (2004). International Accounting and Finance Certification in the Russian Federation. Paper presented at the meeting of the 16th Annual Conference of the International Academy of Business Disciplines, San Antonio, Texas, U.S.A. http://dx.doi.org/10.2139/ssrn.538722

Subotnik, D. (1987). What Accounting Can Learn from Legal Education. Issues in Accounting Education, 2(2), pp.313-324.

Subramaniam, N. (2003). Factors Affecting the Career Progress of Academic Accountants in Australia: Cross-institutional and Gender Perspectives. In Higher Education, 46th ed., Netherlands: Kluwer Academic Publishers, pp.507-542.

http://dx.doi.org/10.1023/A:1027388311727

Tang, Y. (2000).Bumpy Road Leading to Internationalization: A Review of Accounting Development in China. Accounting Horizons, 14(1), pp.93-102.

http://dx.doi.org/10.2308/acch.2000.14.1.93

Tippett, M. (1992). Accounting Education in Australia - The Plight of Accounting Education in Australia: A Review Article. Accounting Education, 1(2), pp.99-127. http://dx.doi.org/10.1080/09639289200000021

Williams, D. Z. (1993). Reforming Accounting Education. Journal of Accountancy, 176(2), pp.76-81.

Williams, J. R. (2000). Challenges Facing Accounting Education. The Practical Accountant, $33(7)$, pp. 68 .

Wolnizer, P. (2004). CPA Australia - A Leader in the Provision of Professional Education. The Changing Education Needs of the Professions. Business/Higher Education Round Table, pp.5-6.

Xiao, Z., and Dyson, J. R. (1999). Chinese Students' Perceptions of Good Accounting Teaching. Accounting Education, 8(4), pp.341-361. http://dx.doi.org/10.1080/096392899330838

Yapa, P. W. S., and Zhen, P. H. (2007). An Analysis of Current Trends in Accounting Professional Development in People's Republic of China. Asian Review of Accounting, 15(1), pp.25-44. http://dx.doi.org/10.1108/13217340710763735

Zeff, S. A. (1989).Does Accounting Belong in the University Curriculum? Issues in Accounting Education, 4(1), pp.1-3. 